\title{
Pendidikan Mental melalui Cerita Anak Tindakan Pasca Banjir di SDN Idaman 1 Kecamatan Patia, Pandeglang
}

\author{
Yasser Arafat ${ }^{1}$ \\ ${ }_{1}^{1}$ Universitas Mathla'ul Anwar Banten
}

\begin{tabular}{|c|c|}
\hline ARTICLE INFO & ABSTRACT \\
\hline $\begin{array}{l}\text { Article History: } \\
\text { Received 30.07.2018 } \\
\text { Received in revised } \\
\text { form 20.08.2018 } \\
\text { Accepted 19.09.2018 } \\
\text { Available online } \\
27.09 .2018\end{array}$ & $\begin{array}{l}\text { This research is entitled, Mental Education through the Story of Children Acting } \\
\text { post Flood in SDN Idaman } 1 \text { Kecamatan Patia, Pandeglang Regency, South } \\
\text { Banten. Focus First stage of research, namely research based on quantitative } \\
\text { data collection and second stage research, namely research that puts forward } \\
\text { quantitative and qualitative approaches to deepen the findings of the research } \\
\text { results. The measured variables consist of mental education research variables } \\
\text { (variable X) and children's stories (variable Y). The research model used is field } \\
\text { observation (direct observation). The research design consists of several stages. } \\
\text { The first stage, a quantitative approach with Structural Equation Modeling } \\
\text { (SEM) techniques will be used to analyze the relationship between mental } \\
\text { education education and children's stories. The second stage, a qualitative } \\
\text { approach with in-depth interview techniques and documentation studies is } \\
\text { used to obtain explanations related to literary learning and its implications for } \\
\text { character formation in students. Data collection methods consist of structured } \\
\text { interviews, read notes, and questionnaire techniques. Data analysis techniques } \\
\text { used are descriptive qualitative.. }\end{array}$ \\
\hline
\end{tabular}

Keywords: Mental Education, Story of Children.

DOI: $10.30653 / 006.201811 .7$

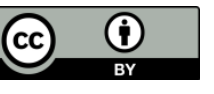

This is an open access article distributed under the terms of the Creative Commons Attribution 4.0 International License, which permits unrestricted use, distribution, and reproduction in any medium, provided the original work is properly cited. () 2018 Yasser Arafat.

\section{PENDAHULUAN}

Bencana di negeri ini tidak pernah selesai. Tidak sedikit anak-anak terhambat keberlangsungan pendidikannya, dampak dari masalah diatas. Sebut saja Sunami di Aceh, gempa di Yogyakarta, di Sumatra, dan seterusnya. Kejadian serupa terjadi di Pandeglang Banten, tepatnya di Desa Idaman Kecamatan Patia. Daerah ini dilanda banjir tahunan yang berakibat dari luapan sungai Cilemer, Cikadueun, dan Cibereum. Sungai yang mengalami pendangkalan yang tidak dapat mengalir lancar ke muara. Permasalahan baru muncul, pemeritah setepat mengambil langkah-langkah tidak tepat. 
Misalnya saja membangun tanggul dipinggiran sungai yang menyebabkan air semakin lama tergenang.

Masyarakat yang berdomisili didaerah itu menanggung bencana bajir tahunan. Tidak sedikit anak-anak yang mengalami ganguan psikologis atau mental yang disebabkan saat banjir datang, mereka terpaksa harus mogok sekolah dan tidak dapat beraktivitas sosial.

Anak-anak sekolah merupakan aset bangsa, keberadaannya sangat penting untuk mendapatkan pendidikan secara layak. Tidak dibiarkan dalam penderitaan bencana. Ada upaya yang akan dilakukan peneliti untuk mencari solusi permasalahan diatas, yakni melakukan penelitian pendidikan mental pasca banjir melalui cerita anak.

Mawardi Labay El-Sulthani (2001: 24), pendidikan adalah proses perubahan sikap dan tatalaku seseorang atau kelompok orang dalam mendewasakan manusia. Pendidikan adalah usaha sadar untuk menyiapkan peserta didik melalui kegiatan bimbingan, pengajaran, dan atau latihan bagi peranannya dimasa yang akan datang.

Metode adalah istilah yang digunakan untuk mengungkapkan pengertian "cara tepat dan cepat dalam melakukan sesuatu, sehingga metode pendidikan mental dapat diartikan yaitu suatu cara tepat dan cepat dalam melakukan latihan, bimbingan, pemeliharaan batin dan watak manusia (mental).

Mengemukakan perkembangan mental akan mejadi mental yang baik atau mental yang jelek, tergantung alam ligkungan atau pendidikan yang akan mempengaruhinya. Bertolak dari pernyataan di atas pendidikan mental sangat penting bagi manusia supaya memiliki mental yang kuat, dengan cara yang tepat dan cepat secara bertahap. Selanjutnya pembinaan mental yang baik yaitu dengan menanamkan Iman dan Taqwa.

Pendapat di atas menunjukkan keselarasan dalam membentuk mental yang sehat dan kuat menurut para pakar pendidikan dapat penulis rumuskan menjadi beberapa aspek antara lain 1) pembinaan mental melalui agama, 2) pembinaan mental melalui pribadi, 3) pembinaan mental melalui lingkungan.

Pembinaan mental melalui agama yaitu dengan cara menanamkan keimanan dan ketakwaan, pembinaan mental melalui pribadi dengan cara mengendalikan emosi, motivasi, berfikir positif, dan mengembangkan potensi diri, sedangkan pembinaan mental melalui lingkungan dengan cara memahami situasi keadaan masyarakat, mengambil nilai-nilai positif dalam keluarga dan masyarakat, dari ketiga aspek itu adanya keterkaitan antara yang satu dan yang lainnya sehingga apabila yang satu tidak terpenuhi maka yang lainnya juga tidak akan maksimal.

Cerita anak hemat peneliti dapat menjawab masalah di atas. Bercermin pada makna sastra (cerita anak), berfungsi sebagai penghibur dan menyampaikan pesan moral. Damono (1979: 1-2) berpendapat, bahwa sastra sebagai lembaga sosial yang menggunakan bahasa sebagai medium, dan bahasa tersebut merupakan ciptaan sosial. Sastra menampilkan gambaran kehidupan dan kehidupan itu adalah suatu kenyataan sosial, dan apabila kita mampu memahami pesan yang terselubung di dalam karya sastra, batin kita lebih tetap dalam menghadapi pekerjaan sehari-hari. Lebih jauh lagi, sastra mengandung gagasan yang mungkin dimanfaatkan untuk menumbuhkan sikap sosial tertentu. Jadi, karya sastra yang baik selalu memberi kesan kepada pembaca untuk berbuat baik, kesan itu dinamakan moral dan amanat, maksudnya karya sastra yang baik mengajak pembaca untuk menjunjung tinggi nilai moral. Sastra berarti kumpulan alat untuk mengajar yang baik. 
Selanjutnya, peneliti mengintegrasikan Pikir dan Dzikir (Pikzi) melalui penelitian, "Pendidikan Mental Melalui Cerita Anak Tindakan Pasca Banjir di SDN Idaman 1 Kecamatan Patia Kabupaten Pandeglang Banten Selatan“. Selanjutnya tujuan penelitian sebagai berikut. 1) Mendeskripsikan pendidikan mental tindakan pasca banjir di SDN Idaman 1 Kecamatan Patia Pandeglang Banten selatan. 2) Mendeskripsikan cerita anak tindakan pasca banjir di SDN Idaman 1 Kecamatan Patia Pandeglang Banten selatan. 3) Mendeskripsikan pendidikan mental dan cerita anak tindakan pasca banjir di SDN Idaman 1 Kecamatan Patia Pandeglang Banten selatan.

\section{METODE}

\section{Populasi dan Sampel}

Populasi dalam penelitian ini adalah seluruh elemen yang terkandung di SDN Idaman 1 Kecamatan Patia, Banten Selatan. Yang terdiri dari enam kelas. Adapun sampel penelitian ditentukan dengan teknis purposive sampling, sampel bertujuan. Tujuan yang dimaksud: 1) responden dapat memberikan data seobjektif mungkin, 2) Responden adalah kategori siswa korban banjir. Berdasarkan penentuan kriteria, maka diperoleh sampel penelitian sebanyak 26 siswa.

\section{Tahapan-Tahapan Penelitian}

Penelitian ini dibagi dalam dua tahap. Tahap Pertama adalah penelitian yang berbasis pengumpulan data kuantitatif dengan kegiatan-kegiatan yang terdiri atas: (1) Penelitian Pendahuluan, termasuk pengkajian teori yang relevan, lokakarya internal tim peneliti, dan studi dokumentasi. (2) Penyusunan Instrumen Penelitian, termasuk ujicoba untuk mengukur validitas dan reliablitas instrumen. (3) Lokakarya Enumerator, rekrutmen dan pembekalan kepada enumerator yang akan diterjunkan ke lapangan. (4) Pengumpulan Data Kuantitatif melalui Survei dilakukan oleh 46 enumerator dan disupervisi oleh 6 supervisor yang masing-masing mengontrol 7-8 enumerator. (5) Pengolahan dan Analisis Data Kuantitatif dengan menggunakan teknik Structural Equation Modeling (SEM). (6) Penulisan Laporan Penelitian Tahap I. Seluruh proses penelitian Tahap I diperkirakan mengambil waktu sekitar dua bulan mulai Mei 2017 sampai Juni 2017.

Tahap Kedua adalah penelitian yang mengedepankan pendekatan kuantitatif untuk memperdalam temuan-temuan dari hasil penelitian Tahap Pertama. Penelitian Tahap II terdiri atas beberapa kegiatan sebegei berikut: (1) Penyusunan Instrumen penggalian data kualitatif. (2) Pelaksanaan Pengumpulan Data Kualitatif m wawancara mendalam (in-depth interview) dengan para informan, dilakukan langsung oleh para peneliti. (3) Pengolahan, Analisis, dan Interpretasi Data Kualitatif oleh tim peneliti. (4) Pelakasanaan Focus Group Discussion (FGD) untuk memverifikasi temuantemuan survei dan wawancara. (5) Penulisan Laporan Penelitian yang menggabungkan hasil penelitian kuantitatif dan kualitatif. (6) Publikasi Hasil Penelitian diharapkan pada jurnal internasional, atau setidak-tidaknya jurnal nasional yang terakreditasi.

Seluruh proses penelitian Tahap II diperkirakan mengambil waktu sekitar lima bulan mulai Juni sampai Juli 2017. Tahapan-tahapan penelitian dapat dilihat pada bagan alir berikut ini. 


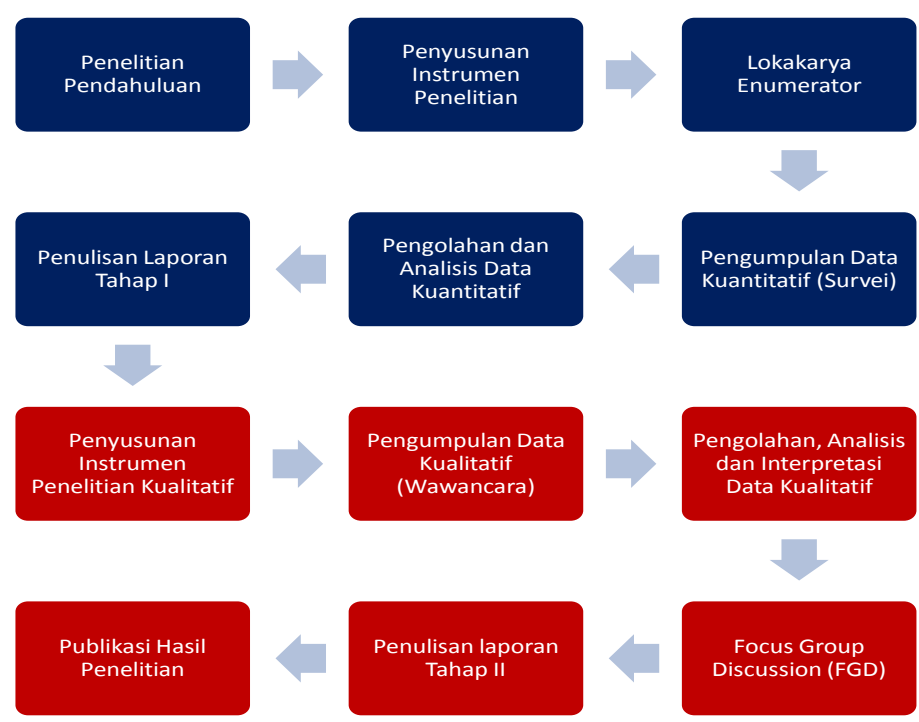

Gambar 1. Alur Penelitian

\section{Model yang digunakan}

Untuk memahami secara mendalam pembentukan karakter siswa melalui pembelajaran sastra yang berorientasi pada pencapaian pendidikan. Untuk itu peneliti harus turun ke lapangan dan berada di sana dalam waktu yang cukup lama untuk mempelajari manusia tertentu dengan mengumpulkan data yang banyak dengan menunjukkan bahwa pelaksanaan penelitian ini terjadi secara alamiah, apa adaya, dalam situasi yang normal yang tidak dimanipulasi keadaan dan kondisinya, menekankan pada deskripsi secara alami. Dengan sifatnya yang natural menurut keterlibatan peneliti secara langsung di lapangan.

Data penelitian adalah data yang mendalam yakni data yang mengandung makna berupa data yang sebenarnya atau data yang asli. Penelitian ini lebih ditekankan pada pengumpulan data guna mendeskripsikan keadaan yang sesungguhnya terjadi di lapangan.

\section{Metode Pengumpulan Data}

Metode pengumpulan data yang digunakan peneliti dalam penelitian ini adalah teknik wawancara terstruktur, teknik baca dan catat, teknik angket (kuesioner), danteknik kuesioner. Teknik pengumpulan data diatas peneliti gunakan untuk menggali data dari responden penelitian.

\section{Teknik Analisis Data}

Peneliti menggunakan teknik analisis data kualitatif deskriptif. Selanjutnya peneliti berpandangan, semua hal yang berupa sistem tidak ada yang patut diremehkan, semuanya penting, dan semuanya mempunyai pengaruh dan kaitannya dengan yang lain.

\section{PEMBAHASAN}

\section{Pendidikan Mental Tindakan Pasca Banjir di SDN Idaman 1 Patia}

Berdasarkan angket penelitian, bahwa 26 responden mengatakan guru Bahasa Indonesia mengajarkan pendidikan mental dalam cerita anak di kelas. Responden 
beralasan bahwa, siswa lebih berkarakter mencerminkan kepribadian yang berbeda mengembangkan Bahasa dan Sastra Indonesia, arti pendidikan mental menambah pengetahuan tentang sastra, menjadikan siswa lebih mandiri, memiliki karakter yang baik, siswa terdidik dan meiliki mental positif. Pendidikan mental yang diajarkan guru Bahasa dan Sastra Indonesia dalam cerita anak yang dimaksud adalah pembelajaran cerpen (kategori cerita anak). Selanjutnya, manfaat tersebut dapat dijabarkan sebagai berikut.

1) Mengembangkan kemampuan berbicara dan memperkaya kosa kata anak, terutama bagi anak-anak batita yang sedang belajar bicara. Kata-kata baru yang didengar melalui dongeng akan semakin memperkaya kosa kata dalam berbicara, sehingga secara tidak langsung kita telah mengajarkan perbendaharaan kata yang banyak kepada anak melalui cerita. Bagi anak-anak usia SD cerita juga bisa melatih dan memperkaya kemampuan berbahasa dan memahami struktur kalimat yang lebih kompleks.

2) Bercerita atau mendongeng merupakan proses mengenalkan bentuk-bentuk emosi dan ekspresi kepada anak, misalnya marah, sedih, gembira, kesal dan lucu. Hal ini akan memperkaya pengalaman emosinya yang akan berpengaruh terhadap pembentukan dan perkembangan kecerdasan emosionalnya.

3) Memberikan efek menyenangkan, bahagia dan ceria, khususnya bila cerita yang disajikan adalah cerita lucu. Secara psikologis, cerita lucu membuat anak senang dan gembira. Rasa nyaman dan bahagia lebih memudahkannya untuk meyerap nilai-nilai yang kita ajarkan melalui cerita.

\section{Cerita Anak Tindakan Pasca Banjir di SDN Idaman 1 Patia}

Responden mengatakan bahwa bagaimana penilaian Anda terhadap cerita anak yang dilakukan oleh guru mata pelajaran Bahasa dan Sastra Indonesia sangat baik. Responden berpendapat, sebanyak 15 responden. Selanjutnya, sembilan responden mengatakan kurang. Mereka beralasan bahwa kelebihan dan kekurangan pembelajaran yang dilakukan oleh guru disebabkan kompetensi guru yang terbatas.

Sebanyak 24 responden mengatakan bahwa cerita anak di kelas yang dilakukan oleh guru mereka lebih senang. Mereka beralasan bahwa cerita anak yang dilakukan oleh guru mengandung nilai-nilai moral. Akan tetapi terdapat dua responden merasa kurang berminat dalam cerita anak yang dilakukan guru disekolah.

Berdasarkan data penelitian 24 responden mengatakan bahwa cerita anak yang dilakukan dikelas bermanfaat. Selanjutnya terdapat dua responden dalam penelitian yang dilakukan peneliti kurang berminat dalam melakukan cerita anak. Manfaat-manfaat yang dimaksud, dijelaskan peneliti di bawah ini.

1) Mentimulasi daya imajinasi dan kreativitas anak, memperkuat daya ingat, serta membuka cakrawala pemikiran anak menjadi lebih kritis dan cerdas. Alur cerita dengan menampilkan bentuk-bentuk emosi akan menumbuhkkembangkan daya imajinasi anak, sehingga ia merasakan senang belajar dengan membayangkan cerita tersebut. Suatu saat ia bisa menuliskan atau menceritakan kembali isi cerita tersebut.

2) Dapat menumbuhkan empati dalam diri anak. Karena itu, cerita yang kita bacakan harus sesuai dengan prinsip yang saya jelaskan di atas. Jika anak dibacakan cerita yang menyentuh jiwa dan perasaan atau bahkan cerita yang bersumber dari pengalaman masa kecil kita, kejadian-kejadian di lingkungan sosial atau tayangan televisi yang menarik dan menyentuh sisi kemanusiaan, maka perasaannya akan 
tersentuh dan ia mulai memiliki rasa empati, mulai dapat membedakan mana yang pantas ditiru dan harus dijauhi.

3) Melatih dan mengembangkan kecerdasan anak. Cerita tidak saja menyenangkan, tetapi memberikan manfaat luar biasa bagi kecerdasan anak secara inteligen (kognitif), emosional (afektif), spiritual dan visual anak. Secara kognitif yaitu akan mempermudah proses pembelajaran pada anak, karena kemampuan berpikir otak lebih mudah menyerap nilai yang terkandung dalam cerita. Secara afektif, cerita akan mempengaruhi suasana hati dan menumbuhkan perasaan-perasaan empati dan positif pada anak. Secara spiritual, cerita juga bisa menggugah kesadaran ruhani, menyentuh bagian terdalam diri anak-anak kita, serta melatih kemampuan, kemauan dan kecerdasan mereka akan keberadaan Tuhan dalam hidup mereka. Hal ini secara psikomotorik akan menuntun mereka untuk bisa mengaplikasikan apa yang mereka dengar dari cerita melalui bentuk-bentuk ibadah. Kisah kehidupan Rasulullah SAW (Sejarah Islam), kisah para sahabat Nabi atau para syuhada merupakan cerita realita yang tepat untuk menstimulasi kecerdasan mereka.

4) Sebagai langkah awal untuk menumbuhkan minat baca anak. Ketertarikan pada cerita akan membuat anak penasaran, ingin mengetahui dan membaca bukunya. Semakin tinggi rasa ingin tahunya, semakin tingi pula minat bacanya, sehingga kelak ia menjadi anak yang suka membaca dan menghargai ilmu.

\section{Pendidikan Mental dan Cerita Anak Tindakan Pasca Banjir di SDN Idaman 1 Patia}

Sebanyak dua puluh enam responden mengatakan bahwa pendidikan mental yang disampaikan oleh guru di hubungkan dengan pembelajaran sastra. Alasan yang dikemukakan oleh siswa bahwa pendidikan mental merupakan bagian dari tujuan cerita anak. Dengan kata lain bahwa cerita anak dapat membantu dalam pendidikan mental.

Bahwa manfaat pendidikan mental dengan cerita anak yang disampaikan oleh guru di hubungkan dengan pembelajaran sastra yaitu membentuk karakter yang baik atau dengan kata alternatif pembentukan karakter. Penelitian dari data 24 responden dari subjek penelitian. Kemudian dua responden mengatakan kurang bermanfaat, dikarenakan kurang menyukai cerita anak. Sebanyak dua puluh lima responden mengatakan bahwa pendidikan mental dengan cerita anak perlu terus dilakukan oleh guru bidang stadi Bahasa dan Sastra Indonesia di sekolah. Mereka pada umumnya beralasan, bahwa pembelajaran tersebut dapat Membantu pembelajaran, mengetahui metode pembelajaran. Selanjutnya peneliti dapat mendeskripsikan di bawah ini.

1) Bercerita atau mendongeng merupakan cara yang efektif untuk memberikan sentuhan manusiawi (human touch) dan menumbuhkan sportivitas anak.

2) Membangun hubungan personal dan mempererat ikatan batin orang tua dengan anak. Ini merupakan manfaat yang paling penting bagi kita juga anak-anak kita, terutama bagi kita yang tidak bisa selalu mendampinginya.

3) Bercerita atau mendongeng merupakan cara sederhana yang memiliki arti dan bisa memberikan dampak luar biasa bagi kepribadian anak-anak kita. Anak-anak kita adalah belahan jiwa kita, seperti matahari yang tiada henti menyinari kehidupan kita sebagai sebuah keluarga. Membahagiakan anak tidak selalu bisa kita lakukan dengan memenuhi kebutuhan materialnya, tetapi lebih dari itu, kebutuhan ruhani, kedekatan dan ikatan batin yang kuat merupakan bentuk kebahagiaan yang utuh dalam membangun dan membentuk kepribadiannya. 


\section{SIMPULAN}

Mentimulasi daya imajinasi dan kreativitas anak, memperkuat daya ingat, serta membuka cakrawala pemikiran anak menjadi lebih kritis dan cerdas. Alur cerita dengan menampilkan bentuk-bentuk emosi akan menumbuhkkembangkan daya imajinasi anak, sehingga ia merasakan senang belajar dengan membayangkan cerita tersebut. Suatu saat ia bisa menuliskan atau menceritakan kembali isi cerita tersebut. Dapat menumbuhkan empati dalam diri anak. Karena itu, cerita yang kita bacakan harus sesuai dengan prinsip yang saya jelaskan di atas. Jika anak dibacakan cerita yang menyentuh jiwa dan perasaan atau bahkan cerita yang bersumber dari pengalaman masa kecil kita, kejadian-kejadian di lingkungan sosial atau tayangan televisi yang menarik dan menyentuh sisi kemanusiaan, maka perasaannya akan tersentuh dan ia mulai memiliki rasa empati, mulai dapat membedakan mana yang pantas ditiru dan harus dijauhi.

Melatih dan mengembangkan kecerdasan anak. Cerita tidak saja menyenangkan, tetapi memberikan manfaat luar biasa bagi kecerdasan anak secara inteligen (kognitif), emosional (afektif), spiritual dan visual anak. Secara kognitif yaitu akan mempermudah proses pembelajaran pada anak, karena kemampuan berpikir otak lebih mudah menyerap nilai yang terkandung dalam cerita. Secara afektif, cerita akan mempengaruhi suasana hati dan menumbuhkan perasaan-perasaan empati dan positif pada anak. Secara spiritual, cerita juga bisa menggugah kesadaran ruhani, menyentuh bagian terdalam diri anak-anak kita, serta melatih kemampuan, kemauan dan kecerdasan mereka akan keberadaan Tuhan dalam hidup mereka. Hal ini secara psikomotorik akan menuntun mereka untuk bisa mengaplikasikan apa yang mereka dengar dari cerita melalui bentuk-bentuk ibadah. Kisah kehidupan Rasulullah SAW (Sejarah Islam), kisah para sahabat Nabi atau para syuhada merupakan cerita realita yang tepat untuk menstimulasi kecerdasan mereka.

Sebagai langkah awal untuk menumbuhkan minat baca anak. Ketertarikan pada cerita akan membuat anak penasaran, ingin mengetahui dan membaca bukunya. Semakin tinggi rasa ingin tahunya, semakin tingi pula minat bacanya, sehingga kelak ia menjadi anak yang suka membaca dan menghargai ilmu.

\section{REFERENSI}

Amelya, R. E. (2009). Peningkatan kemampuan menceritakan kembali cerita anak dengan teknik loci pada peserta didik kelas VII F SMP Negeri 2 Kaliwungu Kudus tahun pelajaran 2008/2009. Skripsi Universitas Negeri Semarang.

Arikunto, S. (2006). Prosedur penelitian: Suatu pendekatan praktis. Jakarta: Rineka Cipta.

Creswell, J. W. (2010). Research design pendekatan kualitatif kuantitatif dan campuran (Penerj. Achmad Fawaid). Yogyakarta: Pustaka Pelajar.

Eneste, P. (2001). Buku pintar sastra Indonesia. Yogyakarta: Hanidita Graha Widya dengan Masyarakat Poetika Indonesia-Yogyakarta.

Fuller, W. A. (2009). Sampling statistics: Wiley series in survey methodology. New Jersey: John Wiley and Sons Inc.

Hatikah, T., \& Mulyanis. (2005). Membina komptensi berbahasa dan sastra Indonesia. Jakarta: Grafindo Media Pratama. 
Herfanda, A. Y. (2005). Menyoal pengajaran seni dan sastra di sekolah (Makalah untuk Talk Show Pengajaran Seni dan Sastra). Tangerang: Tangerang Art Festival.

Herfanda, A. Y. (2006). Mengajarkan apresiasi sastra dengan benar (Makalah diklat pengajaran apresiasi sastra). Jakarta: Pusat Bahasa Depdiknas.

Herfanda, A. Y. (2011). Membentuk karakter siswa dengan pengajaran sastra (Makalah Seminar Internasional Sastra Indonesia). Bandung: Pasca-Sarjana Universitas Gunungjati

Hermawan, D. K. (2012). Faktor dominan dalam pembangunan karakter (Makalah). Bandung: Kopertis IV Jabar Banten.

Karimah, Y. (2013). Peningkatan keterampilan menyimak cerita anak melalui media animasi audio visual pada siswa kelas VI SDI I Ma'had Islam Pekalongan. Skripsi Universitas Negeri Semarang.

Larasati, A. (2009). Peningkatan keterampilan membaca pemahaman cerita anak dengan pendekatan pembelajaran terpadu dan metode GPID pada siswa kelas V SD Negeri Ngijo 03 Gunungpati Semarang tahun ajaran 2008/2009. Skripsi: Universitas Negeri Semarang.

Lukmawati, D. R. (2014). Peningkatan keterampilan bercerita dengan media kaset cerita religi anak pada siswa kelas II B MI Al Iman Banaran Gunungpati Semarang. Skripsi Universitas Negeri Semarang.

Moleong, L. J. (2000). Metodologi penelitian kualitatif. Bandung: Remaja Rosda Karya.

Rendra, W. S. (2008). Megatruh kambuh: Renungan seorang penyair dalam menanggapi kalabendu (Teks pidato saat menerima gelar Doktor Honoris Causa). Yogyakarta: UGM.

Damono, S. D. (1997). Sosiologi sebuah pengantar ringkas. Jakarta: Pusat Pembinaan dan Pengembangan Bahasa Depdikbud.

Surdinata, E. (2012). Faktor dominan dalam pembangunan karakter bangsa (Makalah pelatihan pendidikan karakter bagi dosen perguruan tinggi swasta di lingkungan kopertis wilayah IV). Bandung Kopertis Wilayah IV.

Tarmizi, R, dkk. (2017). Laporan KKN posdaya Unma Banten: Desa Idaman Kecamatan Patia. Pandeglang: LP3M Unma Banten.

Waluyo, M. (2011). Panduan dan aplikasi structural equation modeling. Jakarta: Indeks. 